\title{
Örgüt Kültürü ve Bağlamsal Performans Arasındaki İlişkide Temel Motivasyon Kaynaklarının Biçimleyici Rolü*
}

\author{
İnan ERYILMAZ $\quad$ Asena ALTIN GÜLOVA****
}

$\ddot{O Z Z}$

Bu çalışmanın amacı havacılık sektöründe faaliyet gösteren örgütlerde hâkim olun örgüt kültürü tipini (klan, adhokrasi, hiyerarşi, pazar) belirlemek ve örgüt kültürü tipleri ile çalışanların bağlamsal performans düzeyleri arasındaki ilişkiyi incelemek, bireylerin temel motivasyon kaynaklarının (başarı ihtiyacı, bağlanma ihtiyacı, güç ihtiyacı) varsayılan ilişkide düzenleyici rolünü sinamaktadır. Bu amaç doğrultusunda İstanbul, Ankara, İzmir, Malatya ve Isparta'da faaliyet gösteren kamu ve özel havacılık örgütlerinden 265 katılımcıya araştırma ölçekleri ve demografik değişkenleri içeren anket uygulanmıştır. Araştırma bulgularına göre katılımcılar örgütlerinde en fazla hiyerarş̧ ve klan kültürü algllamaktadırlar. Korelasyon analizi neticesinde en fazla klan kültürü algısı ile bağlamsal performansın ilişkili olduğu bulgulanmıştır. Katılımcıların gü̧̧ ihtiyacının hiyerarşi ve klan kültürleri ile bağlamsal performans arasındaki ilişskileri, başart ihtiyacının ise hiyerarşi kültürü ve bağlamsal performans arasındaki ilişkiyi biçimlediği tespit edilmiştir. Havacılık.

Anahtar Kelimeler: Örgüt Kültürü, Temel Motivasyon Kaynaklarl, Bağlamsal Performans,

JEL Sinıflandırmast: $M 0, M 1, M 12$

\section{The Moderating Role of Basic Motivation Resources in The Relationship Between Organizational Culture and Contextual Performance}

\begin{abstract}
The purpose of this study is to identify the most prevalent types of organizational culture, in the specific context of aviation companies, defined as clan, adhocracy, hierarchy and market cultures, and to investigate the relationship between types of organizational culture and contextual performance. Additionally, this study tests the moderating role of basic motivation resources (need for achievement, need for affiliation, and need for power). To that end, data was collected on a sample of 265 aviation company employees both public and private working in Istanbul, Ankara, Izmir, Malatya and Isparta provinces through survey method. According to findings, participants perceive their organizations to have higher levels of hierarchy and clan culture. The correlation analyses reveal that the type of culture most closely associated with contextual performance is the clan culture. The need for power has a moderating role in the relationship between hierarchy and clan cultures and contextual performance, and the need for achievement moderates the relationship between hierarchy culture and contextual performance.
\end{abstract}

Keywords Organizational Culture, Basic Motivation Resources, Contextual Performance, Aviation

Jel Classification: $M 0, M 1, M 12$

\footnotetext{
* Bu araştırma 27. Yönetim ve Organizasyon Kongresinde sunulan bildiriden türetilmiştir.

*** Dr., Maltepe Üniversitesi Sivil Havac1lık Bölümü, inaneryilmaz@maltepe.edu.tr

*** Doç. Dr. Manisa Celal Bayar Üniversitesi asena.gulova@ cbu.edu.tr
} 


\section{GİRIŞ}

Birey davranışının temel şekillendiricilerinden biri olan kültür, örgüt yazınında önemli bir yer tutmaktadır. Kültür, insanların günlük işlerini yaparken nasıl düşünmeleri, hareket etmeleri ve hissetmeleri gerektiğine ilişkin kanıksanmış sayıltılar örüntüsü olarak tanımlanabilir (Hall, 1959). Başka bir tanıma göre kültür, tarihsel olarak evirilerek gelişen ve bir toplumun üyelerince paylaşılan, öğrenilmiş değerler, tutumlar ve manalar kümesidir (Tayeb, 1988: 42). Kültür, dil ve taklit yoluyla nesilden nesile aktarılan kalıplaşmış ve öğrenilmiş davranışlar bütünü (Barnouw, 1979) ve insan davranışını şekillendiren değerler, görüşler ve sembolik sistemler (Kroeber ve Parsons, 1958) olarak da nitelendirilmektedir. Belki de bilinen en meşhur tanımına göre ise (Hofstede, 1980: 25) kültür, bir grup mensuplarını diğerlerinden ayırt eden değerler sistemi ve kolektif bir zihin programlamasıdır.

Örgüt kültürü konusunun, ülkemizde, yönetim ve organizasyon alanının gündemine girmesi 1980'li yılların ikinci yarısına denk gelmekte ve bu tarihten günümüze, örgüt kültürü konusunda yapılan çalışmalar artan bir ivme göstermektedir (Danışman ve Özgen, 2003). Yapılan çalışmaların, özellikle "değerleniş ve çoğalış" aşamasına denk gelen 1990'lı yıllardan bu yana, örgüt kültürünün ölçümüne ve örgütsel/yönetsel değişkenlerle ilişkisinin ampirik verilere dayalı olarak incelenmesine odaklandığı görülmektedir. Çok sayıda çalışmaya konu olan örgüt kültürü, genel olarak, temel iş süreçlerinden, çalışanların özelliklerinden, somut varlıklardan, yasal düzenlemelerden, örgütsel paydaşlara ilişkin faktörlerden, işletmenin içerisinde faaliyet gösterdiği sosyal ve ekonomik sistemden ve en önemlisi örgütün hayat bulduğu ulusal kültürel bağlamdan etkilenmekte (Köse, Tetik ve Ercan, 2001); verimlilik (Ojo, 2009: 396), iş performansı (Alvesson, 2002: 53), örgütsel bağlılık (Erdem, 2007a; Jun ve Jo, 2011) ve örgütsel vatandaşlık davranışı (Çetin, Şeşen ve Basım, 2012) başta olmak üzere çok sayıda birey/iş̧örgüt düzeyi değişkeni ise etkileyebilmektedir. Kâr amacı güden örgütler bağlamında incelendiğinde ise örgüt kültürü, çalışanların performansı ve dolayısıyla örgütün verimliliği açısından önem arz etmektedir. Belirli bir örgütün çalışanlarının kolektif düşünme tarzını ifade eden örgüt kültürü, örgütlerin devamlılığının ve etkililiğinin sağlanmasında kritik rol oynayan başat faktörlerdendir. Yöneticiler, güçlü bir örgüt kültürü sayesinde, çalışanları örgütsel değerler etrafinda birleştirebilmekte ve örgütsel amaçların gerçekleştirilmesi için çalışanların desteğini alabilmektedir.

Örgütsel amaçların gerçekleştirilmesi noktasında, görev başarımının bir adım ötesinde, çalışanların gönüllü olarak sergiledikleri rol ötesi davranışları niteleyen ve iş performansının bir bileşeni olan bağlamsal performans konusu gündeme gelmektedir. Çalışanların bağlamsal performans motivasyonlarını çözümlemede, örgütsel karakteristiği algılamanın önemi büyüktür (Blakely, Andrews ve Fuller, 2003: 132). Nitekim, örgüte yeni katılan çalışanlar, örgütsel değerleri, normları, inanışları içselleştirdikleri ölçüde karşılılık normunun da bir gereği olarak bağlamsal performans sergileyebilmektedir. Çalışanların değer ve inanışlarının, hâkim olan örgütsel kültürle çatıştığı durumda ise çalışanlar rol ötesi 
davranışlardan kaçınmakta ve örgütle etkileşimlerini, yalnızca ekonomik mübadele çerçevesinde sınırlandırmaktadır (Kraimer, 1997: 437). Bu anlamda, bireyin rol ötesi davranışlar sergilemeye ilişkin motivasyonu, örgüte hâkim olan kültürü benimseme derecesinden ve bu kültürün unsurlarına/gerekliliklerine uyum kapasitesinden bağımsız olarak değerlendirilemez. Buradan hareketle çalışmanın amac1, diğer sektörlere kıyasla farklı örgütsel normları, motifleri terminolojisi, efsaneleri olan havacılık sektöründe faaliyet gösteren örgütlerin, çalışanlarının beyanları doğrultusunda, bu örgütlerde hâkim olan örgüt kültürü tipini (klan, adhokrasi, hiyerarşi, pazar) belirlemek ve örgüt kültürü tipleri ile çalışanların bağlamsal performans düzeyleri arasındaki ilişkiyi incelemektir. Ayrıca çalışmada, bireylerin temel motivasyon kaynaklarının (başarı, bağlanma, güç ihtiyacı) varsayılan ilişkide düzenleyici rol oynayıp oynamadığı ampirik bulgular ekseninde değerlendirmektir.

\section{KAVRAMSAL ÇERÇEVE}

\section{A. Örgüt Kültürü}

Örgüt kültürü, bir örgütte çalışanların davranışlarını etkileyen ve nasıl davranacaklarına dair zihin haritaları ortaya koyan paylaşılan anlam sistemidir (Joiner, 2001: 130). Örgüt kültürü bir dizi değer, inanış, sembol, tören ve mitten oluşmaktadır (Ouchi, 1987: 45).

Örgüt kültürüne dair sınıflandırmalar, kültür araştırmalarının beslendiği farklı disiplinlerin bakış açıları ve alanda çalışan araştırmacıların esas aldığı kuramsal modellere göre farklılaşmaktadır. Bu örgüt kültürü modellerinden biri, yönetim organizasyon yazınında sıklıkla kullanılan "rekabetçi değerler modelidir". Modeli geliştiren Cameron ve Freeman (1991) örgüt kültürü tiplerini, bir eksenin iki ucunda iç odaklılık (klan, hiyerarşi) ile diş odaklılığın (adhokrasi, pazar) ve diğer eksenin iki ucunda esneklik-dinamizm (klan, adhokrasi) ile durağanlıkkontrolün yer aldığı (hiyerarşi, pazar) dört bölümlü bir kartezyen üzerinden sınıflandırmaktadır. Klan kültürü, çalışanlara ve müşterilere yakın ilgi gösterilen, insan ilişkilerinin ve arkadaşlığın ön plana çıktığı, ilişkilerin başarıdan daha fazla tatmin yarattığı örgüt kültürü tipini tanımlamaktadır (Çetin, Şeşen ve Basım, 2012). $\mathrm{Bu}$ tip kültürün hâkim olduğu örgütlerde, hiyerarşik kurallardan ziyade paylaşım, uyum ve bağlılık ön plana çıkmaktadır (Yücel ve Koçak, 2014). Bir amaç etrafında toplanan esnek yapıları niteleyen adhokrasi kültürü (Latince ad hoc, amaca özel, geçici ve cracy, yönetim biçimi sözcüklerinin birleşiminde oluşur), girişimci, dış odaklı ve yenilikçi özelliği ön plana çıkan kültürdür. Adhokratik örgütler, çalışma alanında esnekliğin ve inisiyatifin hâkim olduğu, statü ve pozisyonların çok fazla önemsenmediği kültürlerdir. Proje bazlı örgütler, şebeke ve sanal örgütlenmeler adhokrasi kültürüne örnek olarak verilebilir. Bürokratik örgütlerin tersi olarak konumlandırabileceğimiz adhokratik örgütler, çevrede meydana gelen değişimlere uyum kabiliyeti yüksek, inovasyona yatkın, hiyerarşik yapının basık ve biçimselleşmenin düşük düzeyde olduğu, kural ve prosedürlerin asgari düzeyde tutulduğu yapılar olarak nitelenebilir (Oral-Ataç, 2018: 74). Pazar kültürü, dış odaklı, rekabetin ön plana çıktığı, pazar payını sürekli artırmaya odaklanan ve planlamanın, performansın, örgütün etkililiğinin vurgulandığı örgüt kültürü tipidir. 
Aynı zamanda, pazar kültüründe, kontrollü olmak ve durağanlık da önemlidir. Amaçların önceliklendirildiği bu örgüt kültüründe, başarı, sonuç odaklılık ve nam ön plana çıkmaktadır. Çalışanlar, piyasa mekanizmasının işlediği bir ortamda, örgütsel amaçlara kişisel olarak sundukları katkının karşılığını almaktadır (Erdem, 2007b). Hiyerarşi kültürü, kural ve prosedürlerin harfiyen takip edilmeye çalışıldığ ve usulün esastan önce geldiği bürokratik örgüt kültürünü tanımlamak için kullanılır. Bu kültürde çalışanlar, belirsizlikten ve çatışmadan kaçınma eğilimi gösterirler. Hiyerarşi kültüründe, tahmin edilebilirlik ve istikrar temel amaçlar; kontrol ve sorumluluk ise temel değerler olarak görülür (Yücel ve Koçak, 2014). Biçimsel iletişim kanallarının kullanıldığı bu tip örgütlerde lider uzman, bilgili ve kontrolcüdür (Berrio, 2003; Cameron ve Freeman, 1991; Cameron ve Quinn, 2006; Erdem, 2007a). Bu dörtlü yap1, kültürel değerler ile yap1, strateji ve çevre arasındaki uyumdan beslenmekte; çevrenin ve örgütün ihtiyaçlarının bir fonksiyonu olarak farklı örgütlerde farklı şekillerde ortaya çıkmaktadır (Erdem, 2007a).

Örgüt kültürünün, sosyal bir tutkal ve davranışları biçimlendiren bir kontrol mekanizması işlevi görerek (Şeşen, 2013: 550), a) rekabet avantajı ve finansal başarı, b) üretkenlik, kalite ve moral, c) yenilikçilik, d) birleşme ve satın almada kıyaslama, d) birey-örgüt uyumu ve e) liderlik faaliyetlerine yön verme gibi çok çeşitli sonuçlara etki edeceği belirtilmektedir (DuBrin, 2005: 282). Nitekim, Cameron ve Quinn ile Cameron ve Freeman tarafindan geliştirilen tipolojiye dayanan araştırma modellerinin kullanıldığı çalışmalar, farklı örgüt tiplerinin birey veya örgüt düzeyinde farklı sonuçlarla ve farklı düzeylerde ilişkilendiği sonucuna varmıştır. Örneğin, klan ve adhokrasi kültürlerinin çalışanların duygusal ve normatif bağlılıklarını artırıcı etkisi olduğu; pazar ve hiyerarşi kültürlerinin ise çalışanların devam bağlılığ 1 ile daha yüksek düzeyde ilişkili olduğu tespit edilmiştir (Acar, 2013; Yücel ve Koçak, 2014). Örgütsel bağl1lık ve örgüt kültürü tipleri arasındaki ilişkilerin incelendiği başka bir çalışmada, klan ve adhokrasi kültürünün örgütsel bağlılık ile pozitif ilişkisine karşın, hiyerarşi ve pazar kültürlerinin negatif ilişkisine dair kanıtlar elde edilmiştir (Erdem, 2007a). Çalışmanın bu bulgusunun, klan kültürünün Türk toplumsal kültürünün paternalistik eğilimleri ile uyumu bağlamında anlamlı olduğu yorumu yapılmıştır. Bir başka çalışmada, adhokrasi ve klan tipi örgütlenmenin, yenilikçilik üzerindeki anlamlı etkisine karşın, hiyerarşik kültür tipinin olumsuz etkisi bulgulanmıştır (Çetin ve Topaloğlu, 2018). Cameron ve Quinn'in örgüt kültürü türlerinin incelendiği araştırmalara konu edilen diğer bazı değişkenler ise kariyer engelleri (Ersarı, İşcan ve Naktiyok, 2016), örgütsel sessizlik (Çavuşoğlu ve Köse, 2016), düşük ve yüksek bağlamlı iletişim tarzları (Kandemir, Tekeli ve Özdaşl1, 2016), iş yeri zorbalığı (Kuşcu, 2011), yönetsel davranışlar (Topaloğlu ve Kara, 2004), liderlik (Karcıoğlu ve Timuroğlu, 2004) olarak karşımıza çıkmaktadır.

\section{B. Temel Motivasyon Kaynakları}

Çalışma yaşamı açısından ele alındığında motivasyon, beklentilerinin ve ihtiyaçlarının karşılanması halinde, bireyin kendi isteği doğrultusunda örgütsel amaçları gerçekleştirmeye yönelik yüksek düzeyde çaba göstermesini ifade 
etmektedir (Paşamehmetoğlu ve Yeloğlu, 2013). Bu anlamda motivasyon, performansı artırıcı bir faktör olarak belirmektedir. Motivasyonun doğasını anlamaya yönelik geliştirilen kuramlar, işin özellikleri, örgüt kültürü ve çalışanların psikolojisi gibi çeşitli unsurlar üzerinden, çalışanların sergiledikleri davranışları ve bu davranışlara temel oluşturan süreçleri açıklamaya çalışmaktadır. Bu motivasyon kuramları literatürde ihtiyaç/kapsam ve süreç kuramları olarak iki kısımda incelenmektedir. İhtiyaç kuramları (Maslow'un ihtiyaçlar hiyerarşisi yaklaşımı, Alderfer'in ERG yaklaşımı, Herzberg'in çift faktör kuramı, Başarma ihtiyacı kuramı) insan gereksinimlerini genel olarak sinıflandırmakta, insanı belirli davranışlara sevk eden içsel faktörleri anlamaya odaklanmakta, ancak diğer taraftan, bireysel farklılıkların motivasyon sürecindeki etkilerini yadsımaktadır. Süreç kuramları ise, çalışanların hangi amaçlar tarafından ve nasıl motive olduklarını, birey düzeyinde irdeleyen yaklaşımlardır (Koçel, 2011: 628). İhtiyaçların, kişiyi bir davranışa sevk eden salt faktör olmadığ 1 önermesinden doğan süreç kuramları, kişinin beklentileri ve eşitlik algısı gibi çok sayıda diğer içsel ve dışsal faktörün motivasyondaki rolüne odaklanmaktadır. Bu bağlamda, her ne kadar kapsam kuramları altında sınıflandırılsa da McClelland'ın $(1961,1985)$ ihtiyaçlar kuramı, bireysel farklılıklar üzerine inşa edilmesi noktasında emsallerinden farklılaşan bir yaklaşımdır. McClelland'ın (1985) ihtiyaçlar kuramı, davranış ve tutumları etkileyen gereksinimleri başarı ihtiyacı, bağlanma ihtiyacı ve güç ihtiyacı olmak üzere üç gruba ayırmıştır. Başarı ihtiyacı yüksek olan bireyler, başarması güç hedefler ve anlamlı amaçlar peşinde koşmakta ve daha yüksek başarı elde etmek için çabalamaktadır. Bu tip bireyler daha fazla performans göstermektedir (McClelland, 1985: 238-246). Bağlanma ihtiyacı yüksek bireyler, yakın ve samimi ilişkiler kurma arzusundadır. Liderlik konusunda problemler yaşamalarına rağmen, ilişki kurma arayışındaki bireyler grup çalışmalarına ve uyuma önem vermektedir (George, Jones ve Sharbrough, 2012: 52). Son olarak, güç ihtiyacı yüksek olan bireyler, güç ve otorite kaynaklarını genişleterek diğerlerini etkileme arayışındadır (Koçel, 2011:627). Bu tip ihtiyacı yüksek olan bireyler, duygusal ve davranışsal etki kurmak istemekte, bu amaç doğrultusunda ilişki ağı kurma ve etki alanını genişletme eğiliminde olmaktadır. Çalışanın hangi ihtiyacının baskın olduğunun bilgisi, personel seçiminden terfilere, hedef belirlemeden performans değerlendirmeye kadar çalışanlarla ilgili her türlü konuda yöneticilerin işini kolaylaştıracaktır. Dahası, ihtiyaçları doyurulan ve örgütün amaçları/ihtiyaçları ile kişisel amaçları arasında belirli bir dengeyi kurabilen çalışanların, görev performansının ötesinde rol üstü davranışlara yönelmesi mümkün olabilecektir.

\section{Bağlamsal Performans}

Bağlamsal performans iş tanımlarında yer almayan rol ötesi davranışları ifade etmektedir (Motowidlo, Borman ve Schmit, 1997; Jawahar ve Carr, 2007; Goodman ve Svyantek, 1999). Bağlamsal performans, iş arkadaşlarına yardım etme ve destekleme, verilen görevlere gönüllü olma, bu görevleri gerçekleştirme esnasında çalışma arkadaşlarının öğrenmesine katkıda bulunma, kişisel sorumluluğun bulunmadığı durumlarda dahi başkaları için görev yapma, bilgiyi 
paylaşma ve fazladan çaba harcama gibi eylemlerden oluşmaktadır (Borman ve Motowidlo, 1997: 10; Goodman ve Svyantek,1999; Van Scotter, Motowidlo ve Cross, 2000). Örgütün sosyal ve psikolojik çevresini şekillendirerek görev başarımı için katalizör rolü üstlenen bağlamsal eylemler, örgütün etkililiğine katkıda bulunmaktadır. İş performansının önemli bir unsuru olan bağlamsal performans, (görev performansının aksine) farklı işler ve görevler arasında farklılaşmayan, kişilikle ve içsel faktörlerle yakından ilişkili, örgüte/yöneticiye ve iş arkadaşlarına fayda sağlayan ve iş tanımlarında/rol davranışlarında sözü edilmeyen türden faaliyetleri ifade eder (Borman ve Motowidlo, 1997; Meydan, Dirik ve Eryılmaz, 2018).Çalışanların, örgütün sunduğu koşullardan memnuniyetleri ölçüsünde ve örgütle aralarındaki mübadelenin kalitesine ilişkin algıları uyarınca bağlamsal performanslarının artacağı düşünülmektedir (Bağcı, 2014). Ayrıca, bağlamsal performansın en önemli öncüllerinin kişilik, ulusal kültür, örgüt kültürü ve liderlik olduğu (Reilly ve Aronson, 2012) önermesinden hareketle farklı örgüt kültürü tiplerinin bağlamsal performans ile etkileşiminin incelenmesi konusu gündeme gelmektedir. Örgüt kültürünün, uygun olan ve olmayan davranış kodlarını taşıması, örgüt üyelerinin paylaşacağı değerlere zemin hazırlaması, belirli davranışları teşvik etmesi ve belirli konularda caydırıcı rol üstlenmesi, bağlamsal performansın ortaya çıkıp çıkmaması noktasında belirleyici bir faktör olmasına yol açmaktadır. Çalışanların güçlendirildiği, beklentilerin ve amaçların açıkça belirlendiği, adaletin gözetildiği kültürlerde bağlamsal performansın ortaya çıkma olasılığının artacağ 2012). Örgüt, grup ve birey düzeyinde verimlilik, müşteri memnuniyeti, yenilikçi davranışlar gibi çeşitli sonuçlar üreten bağlamsal performansın, çalışanların davranışlarını şekillendiren temel motivasyonlarından etkileneceği öngörülmektedir.

İlgili literatürden hareketle;

Hipotez 1. Çalışanların örgüt kültürüne dair algıları ile bağlamsal performansları ilişkilidir.

Hipotez 2. Çalışanların örgüt kültürüne dair algıları ile bağlamsal performans arasındaki ilişkide temel motivasyon kaynakları düzenleyici rol oynar.

\section{YÖNTEM}

Çalışmanın temel varsayımı, çalışanların örgüt kültürüne dair algılarının bağlamsal performans düzeyleri ile ilişkili olduğudur. Araştırma, örgüt kültürübağlamsal performans ilişkisini bireyin motivasyon kaynakları bağlamında değerlendirmesi açısından keşfedici bir nitelik taşımaktadır. Araştırmanın modeli Şekil 1'de görülmektedir. 
Şekil 1. Araştırma Modeli

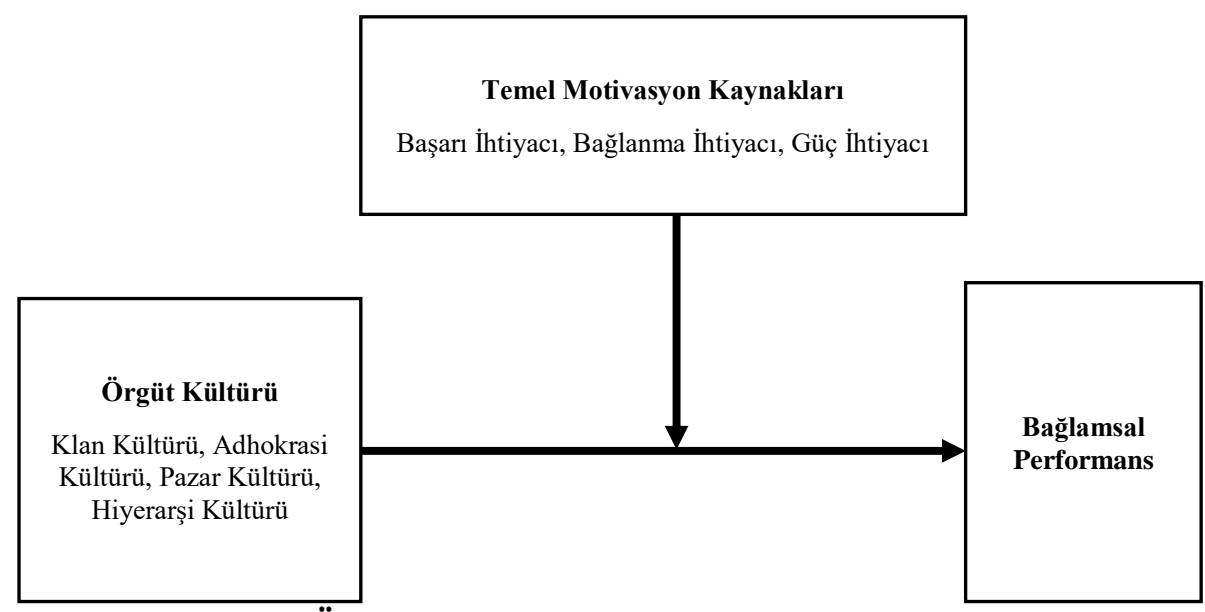

\section{B. Evren ve Örneklem}

Araştırmanının evrenini kamuda ve özel sektörde faaliyet gösteren havacılık sektörü çalışanları oluşturmaktadır. Çalışmanın amacı doğrultusunda, kolayda örneklemi yöntemi kullanılarak, İstanbul, İzmir, Ankara, Malatya ve Isparta illerinde çalı̧̧makta olan 294 havacılık sektörü çalışanından veri toplanmıştır. Anket yönteminin kullanıldığı çalışmada, yanlış ve eksik doldurulan 29 anketin çıkartılması neticesinde 265 katılımcı üzerinden analizler yapılmıştır.

Araştırmaya dahil edilen havacılık sektörü çalışanlarının 58'i $(\% 21,9)$ kadın ve 207'si $(\% 78,1)$ erkektir. Katılımcıların 15'i $(\% 5,7)$ ilköğretim, 15'i $(\% 5,7)$ lise, 35'i (\%13,2) meslek yüksek okulu, 137'si (\%51,7) üniversite ve 63'ü $(\% 23,8)$ lisans üstü bir program mezunudur. Katılımcıların ortalama yaşı 39 , ortalama iş tecrübeleri 15,9 yıl ve mevcut işyerlerinde ortalama çalışma süreleri ise 8,5 yıldır.

\section{C. Ölçüm Araçları}

Anket yönteminin benimsendiği araştırmada veri toplama araçları olarak örgüt kültürü ölçeği, temel motivasyon kaynakları ölçeği ve bağlamsal performans ölçeği ile cinsiyet, yaş, sektör, eğitim ve iş tecrübesi demografik değişkenlerini içeren soru formu kullanılmıştır. Katılımcılardan toplanan veriler SPSS ve AMOS yazılımları aracılığıyla analize tabi tutulmuştur.

Örgüt kültürü ölçeği: Havacılık sektöründe çalışan katılımcıların algıladıkları örgüt kültürü tiplerini ortaya çıkarmak için Cameron ve Quinn (2006: 26-28) ile Cameron ve Freeman (1991) modeli üzerine geliştirilen 24 madde ve 4 alt boyuttan oluşan ölçek kullanılmıştır. Ulusal yazında da sıklıkla kullanılan ölçek, geçerli ve güvenilir sonuçlar vermiştir (Erdem, 2007a; Aydıntan ve Aktan, 2016). Dört boyutlu yapısı üzerine yapılan DFA (doğrulayıcı faktör analizi) sonucunda, ölçeğin uyum iyiliği değerleri $\chi 2 / \mathrm{sd}=2,774$, RMSEA $=0,065, \quad$ CFI $=0,897$, AGFI=0,881 olarak faktör yapısına uyumlu olarak tespit edilmiştir. Ölçeğin alt boyutlarının iç tutarlılık katsayıları ise klan kültürü için 0,91 , adhokrasi kültürü için 0,92 , pazar kültürü için 0,88 ve hiyerarşi kültürü için 0,82 olmak üzere güvenilir aralıkta bulunmuştur. 
Temel motivasyon kaynakları: Çalışanların temel motivasyon kaynaklarını ölçmek için Antalyalı ve Bolat (2017) tarafindan geliştirilen, 24 maddelik temel motivasyon kaynakları ölçeğinin, üç temel motivasyon kaynağını (başarı, bağlanma ve güç ihtiyacı) ölçümleyen 18 maddelik formu kullanılmıştır. Üç boyutlu olarak kullanılan ölçeğe ilişkin uyum iyiliği değerleri ise $\chi 2 / \mathrm{sd}=2,912$, RMSEA $=0,079, \mathrm{CFI}=0,885, \mathrm{AGFI}=0,871$ olarak tespit edilmiştir. Ölçeğin alt boyutlarının iç tutarlılık katsayıları ise başarı ihtiyacı için 0,82 , bağlanma ihtiyacı için 0,81 ve güç ihtiyacı için 0,88 olmak üzere güvenilir aralıkta bulunmuştur.

Bağlamsal performans: Havacılık sektörü çalışanlarının bağlamsal performansını ölçmek için Karakurum (2005) tarafından geliştirilen iş performansı ölçeğinin, bağlamsal performansı ölçen 5 maddelik bölümünden yararlanılmıştır. Tek boyutlu ölçeğin yap1 geçerliliğine ilişkin uyum iyiliği değerleri $\chi 2 / \mathrm{sd}=3,012$, RMSEA $=0,054, \mathrm{CFI}=0,870, \mathrm{AGFI}=0,895^{\prime}$ dir. Ölçeğin iç tutarlılık katsayısı ise 0,91 olarak bulunmuştur. Tüm ölçeklerde ifadelere katılım 5'li Likert ölçeği ile 1Hiç Katılmıyorum'dan 5-Tamamen Katılıyorum'a doğru) derecelendirilmiştir.

\section{Araştırmanın Bulguları ve Sonuçları}

Doğrulayıc1 faktör analizi sonucu faktör yapısı doğrulanan ölçekler aracılığıyla, örgüt kültürü, temel motivasyon kaynakları, bağlamsal performans arasındaki varsayılan ilişkileri görmek ve hipotezleri test etmek amacıyla korelasyon testi yapılmıştır. Bulgular Tablo 1'de sunulmuştur.

Tablo 1. Araştırma Değişkenlerine İliş̧kin Korelasyon Değerleri

Değişkenler

2.Adhokrasi $K$.

3. Pazar K.

4. Hiyerarşi K.

5. Başarı İ.

6. Bağlanma İ.

7. Güç İ.

8. Bağlamsal $P$.
1. Klan K.
Ort. ss 1

$2,91 \quad 1,11 \quad(\mathbf{0 , 9 1})$

$2,64 \quad 1,14 \quad, 843^{* * *}$

$2,74 \quad 1,11 \quad, 736 * * \quad, 786^{* *}$

3,26

$3,76 \quad 0,74$

$4,16 \quad 0,60$

$3,34 \quad 0,85$

3,83

2

, $277 * *$

, $135^{*}$

$135 *$
3

4

5

6

7

${ }^{*} \mathrm{p}<0,05,{ }^{*} \mathrm{p}<0,01$, Parantez içi değerler iç tutarlılık katsayılarıdır. $(\mathbf{0 , 8 8})$

, $661 * * \quad(\mathbf{0 , 8 2})$

$, 242 * * \quad, 148 * * \quad(\mathbf{0 , 8 2})$

$, 251 * * \quad, 248 * * \quad, 371 * * \quad(\mathbf{0 , 8 1})$

$, 154 * \quad, 155 *$

$, 456 * * \quad, 359^{* *} \quad, 373^{* *} \quad, 243 * *$

$(\mathbf{0 , 9 1 )}$

Korelasyon analizi bulgularına göre, bağlamsal performans ile sirasiyla klan kültürü $(\mathrm{r}=0,56, \mathrm{p}<0,01)$, pazar kültürü $(\mathrm{r}=0,49, \mathrm{p}<0,01)$, adhokrasi kültürü $(\mathrm{r}=0,47, \mathrm{p}<0,01)$ ve hiyerarşi kültürü $(\mathrm{r}=0,45, \mathrm{p}<0,01)$ arasında istatistiksel olarak anlamlı ve pozitif yönlü ilişkiler görülmüştür. Örgüt kültürü tipleri ile temel motivasyon kaynaklarının tüm alt boyutları arasında da istatistiksel açıdan olumlu ve anlamlı ilişki görülmüştür. Ayrıca, bağlamsal performans ile temel motivasyon kaynakları arasında en yüksek ilişkiler sırasıyla bağlanma ihtiyacı $(r=0,37, p<0,01)$, başarı ihtiyacı $(\mathrm{r}=0,35, \mathrm{p}<0,01)$ ve güç ihtiyacı $(\mathrm{r}=0,24, \mathrm{p}<0,01)$ alt boyutlarında görülmüştür. Korelasyon analizi bulguları neticesinde birinci hipotez desteklenmiştir.

Korelasyon analizinde tespit edilen anlamlı bulgulardan yola çıkılarak, örgüt kültürü alt boyutlarının bağlamsal performans üzerindeki etkisini yordayan 
ve bu ilişkilerde temel motivasyon kaynaklarının rolünü inceleyen regresyon modelleri kurulmuştur.

Araştırmanın düzenleyici etki öngören hipotezini sınamak amacıyla bağlamsal performansın bağımlı değişken, örgüt kültürü tiplerinin bağımsız değişkenler olduğu ve temel motivasyon kaynaklarının her birinin etkileşim değişkeni yaratılmak suretiyle modellere dahil edildiği hiyerarşik regresyon analizleri yapılmıştır. Düzenleyici etki analizleri Aiken ve West'in (1991) önerdiği üzere çoklu doğrusallık sorununu aşmak adına yordayıcıların merkezileştirilmesi ve elde edilen yeni skorların çarpımından etkileşim değişkenlerinin üretilmesiyle gerçekleştirilmiştir (Tablo 2).

Tablo 2. Araştırma Değişkenlerine İlişskin Hiyerarşik Regresyon Analizi

\begin{tabular}{|c|c|c|c|c|c|c|c|c|c|}
\hline $\begin{array}{c}\text { Bağımlı } \\
\text { Değişken }\end{array}$ & Adım & Bağımsız Değişken & Beta & $\mathbf{t}$ & $\mathbf{p}$ & $\mathbf{F}$ & (p) & $\mathbf{R}$ & $\mathbf{R} 2$ \\
\hline \multirow{9}{*}{$\begin{array}{l}\text { Bağlamsal } \\
\text { Performans }\end{array}$} & 1 & Klan K. & 0,942 & 3,718 & 0,000 & 83,221 & 0,000 & 0,623 & 0,388 \\
\hline & & Başarı İ. & 0,474 & 3,580 & 0,000 & & & & \\
\hline & 2 & Klan*Başarı & $-0,513$ & $-1,705$ & 0,089 & 56,854 & 0,000 & 0,629 & 0,395 \\
\hline & 1 & Klan K. & 0,725 & 1,780 & 0,076 & 77,522 & 0,000 & 0,610 & 0,372 \\
\hline & & Bağlanma İ. & 0,303 & 2,249 & 0,025 & & & & \\
\hline & 2 & Klan*Bağ. & -0.252 & -0.552 & 0,581 & 51,646 & 0,000 & 0,610 & 0,373 \\
\hline & 1 & Klan K. & 0,933 & 4,917 & 0,000 & 70,292 & 0,000 & 0,560 & 0,313 \\
\hline & & Güç İhtiyacı & 0,420 & 3,276 & 0,000 & & & & \\
\hline & 2 & Klan*Güç & 0.501 & $-2,124$ & 0,001 & 48,994 & $\mathbf{0 , 0 0 0}$ & 0,600 & 0,360 \\
\hline \multirow{9}{*}{$\begin{array}{l}\text { Bağlamsal } \\
\text { Performans }\end{array}$} & 1 & Adhokrasi K. & 0,514 & 1,812 & 0,071 & 55,761 & 0,000 & 0,546 & 0,299 \\
\hline & & Başarı İ. & 0,315 & 2,470 & 0,014 & & & & \\
\hline & 2 & Adhokrasi*Başarı & $-0,110$ & -0.337 & 0,737 & 37,086 & 0,000 & 0,47 & 0,299 \\
\hline & 1 & Adhokrasi K. & $-0,092$ & $-0,203$ & 0,840 & 57,057 & 0,000 & 0,551 & 0,303 \\
\hline & & Bağlanma İ. & 0,136 & 0.944 & 0,346 & & & & \\
\hline & 2 & Adhokrasi*Bağ. & 0,561 & 1,120 & 0,264 & 38,493 & 0,000 & 0,554 & 0,307 \\
\hline & 1 & Adhokrasi K. & 0,666 & 3,194 & 0,002 & 45,503 & 0,000 & 0,508 & 0,258 \\
\hline & & Güç İhtiyacı & 0,301 & 2,432 & 0,064 & & & & \\
\hline & 2 & Adhokrasi*Güç & $-0,266$ & $-1,070$ & 0,285 & 30,734 & 0,000 & 0,511 & 0,261 \\
\hline \multirow{9}{*}{$\begin{array}{l}\text { Bağlamsal } \\
\text { Performans }\end{array}$} & 1 & Pazar K. & 0,641 & 2,305 & 0,022 & 57,191 & 0,000 & 0,551 & 0,304 \\
\hline & & Başarı İ. & 0,355 & 2,513 & 0,013 & & & & \\
\hline & 2 & Pazar*Başarı & $-0,257$ & $-0,768$ & 0,443 & 38,265 & 0,000 & 0,553 & 0,306 \\
\hline & 1 & Pazar K. & 0,100 & 0.238 & 0,812 & 58,690 & 0,000 & 0,556 & 0,309 \\
\hline & & Bağlanma İ. & 0,162 & 1,117 & 0,265 & & & & \\
\hline & 2 & Pazar*Bağ. & 0,368 & 0,776 & 0,348 & 39,268 & 0,000 & 0,558 & 0,311 \\
\hline & 1 & Pazar K. & 0,752 & 3.748 & 0,000 & 48,762 & 0,000 & 0,521 & 0,271 \\
\hline & & Güç İhtiyacı & 0,356 & 2.611 & 0,010 & & & & \\
\hline & 2 & Pazar*Güç & -0.372 & -1.447 & 0,141 & 33,382 & 0,000 & 0,527 & 0.277 \\
\hline
\end{tabular}


Inan Eryılmaz \& Asena A. Gülova / Örgüt Kültürü ve Bağlamsal Performans Arasındaki İlişkide Temel Motivasyon Kaynaklarının Biçimleyici Rolü

\begin{tabular}{|c|c|c|c|c|c|c|c|c|c|}
\hline \multirow{9}{*}{$\begin{array}{l}\text { Bağlamsal } \\
\text { Performans }\end{array}$} & 1 & Hiyerarşi K. & 0,868 & 4,223 & 0,000 & 54,854 & 0,000 & 0,513 & 0,263 \\
\hline & & Başarı İ. & 0,727 & 4,334 & 0,000 & & & & \\
\hline & 2 & Hiyerarşi*Başarı & 0,869 & $-2,687$ & $\mathbf{0 , 0 0 8}$ & 39,884 & $\mathbf{0 , 0 0 0}$ & 0,644 & 0,314 \\
\hline & 1 & Hiyerarşi K. & 0,576 & 1,769 & 0,078 & 51,072 & 0,000 & 0,530 & 0,281 \\
\hline & & Bağlanma İ. & 0,351 & 2,563 & 0,011 & & & & \\
\hline & 2 & Hiyerarşi *Băg. & $-0,221$ & -0.587 & 0,558 & 34,078 & 0,000 & 0,531 & 0,281 \\
\hline & 1 & Hiyerarşi K. & 0,835 & 4,170 & 0,000 & 41,033 & 0,000 & 0,488 & 0,233 \\
\hline & & Güç İhtiyacı & 0,514 & 3,037 & 0,003 & & & & \\
\hline & 2 & Hiyerarși *Güç & 0,578 & $-2,106$ & 0,009 & 29,193 & 0,000 & 0,618 & 0,381 \\
\hline
\end{tabular}

Tablo 2'de yer alan modellere göre, bağlamsal performansın bağıml değişken, klan kültürü ile güç ihtiyacının bağımsız değişkenler olarak tanımlandığı modelin açıklama gücü \%31 olarak gerçekleşmiştir. Klan kültürü x Güç etkileşim teriminin modele dahil edilmesi ile modelin açıklama gücünde $\% 5$ oranında anlamlı artış izlenmiş ve modelin açıklama gücü \%36'ya yükselmiştir. Klan x Başarı ve Klan x Bağlanma etkileşim değişkenlerinin olduğu modeller ise istatistiksel açıdan anlamlı bulunmamıştır.

Bağlamsal performansın bağımlı değişken, adhokrasi kültürü ve pazar kültürünün bağımsız değişkenler olarak tanımlandığı modellere, temel motivasyon kaynakları etkileşim değişkeni yaratılmak suretiyle dahil edildiğinde, modellerin açıklama gücünde istatistiksel açıdan anlamlı değişim olmadığı görülmüştür.

Bağlamsal performansın bağımlı değişken, hiyerarşi kültürü ile başarı ihtiyacının bağımsız değişkenler olarak tanımlandığı modelin açıklama gücü \%26 olarak gerçekleşmiştir. İkinci adımda modele dahil edilen etkileşim değişkeni (Hiyerarşi x Başarı) modelin açıklama gücünü \%31'e yükseltmiştir. Son olarak, bağlamsal performansın bağımlı değişken, hiyerarşi kültürü ile güç ihtiyacının bağımsız değişkenler olarak tanımlandığı modelin açıklama gücü \%23 olarak gerçekleşmiştir. İkinci adımda modele dahil edilen etkileşim değişkeni (Hiyerarşi x Güç) modelin açılama gücünü \%38'e yükseltmiştir.

Düzenleyici etki testlerine göre, çalışanların örgüt kültürü algıları ile bağlamsal performansları arasındaki ilişkilerin bir kısmı temel motivasyon kaynakları tarafından düzenlenirken, bir kısmı için düzenleyicilik söz konusu olmadığından, ikinci hipotez kısmen desteklenebilmiştir.

Şekil 2. Düzenleyici Etki Analizi Sonucu

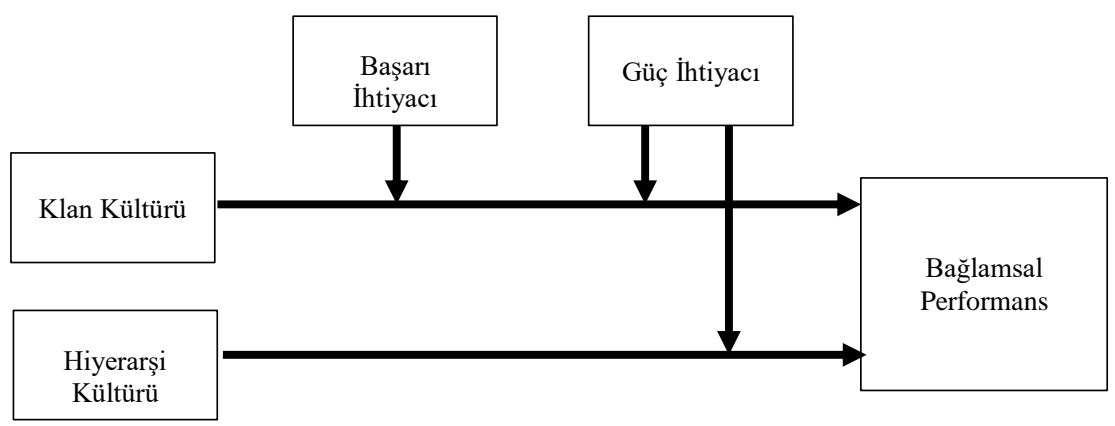


Araştırmanın hipotez testleri neticesinde istatistiksel açıdan anlamlı bulunan modeller, Şekil 2'de görülmektedir. Ayrıca hiyerarşik regresyon analizleri sonucunda anlamlı bulunan ilişkilere dair çizilen moderatör etki grafikleri Şekil 3, Şekil 4 ve Şekil 5'te yer almaktadır.

Şekil 3. Klan Kültürü ile Bağlamsal Performans Arasındaki İlişkide Güç İhtiyacının Rolü

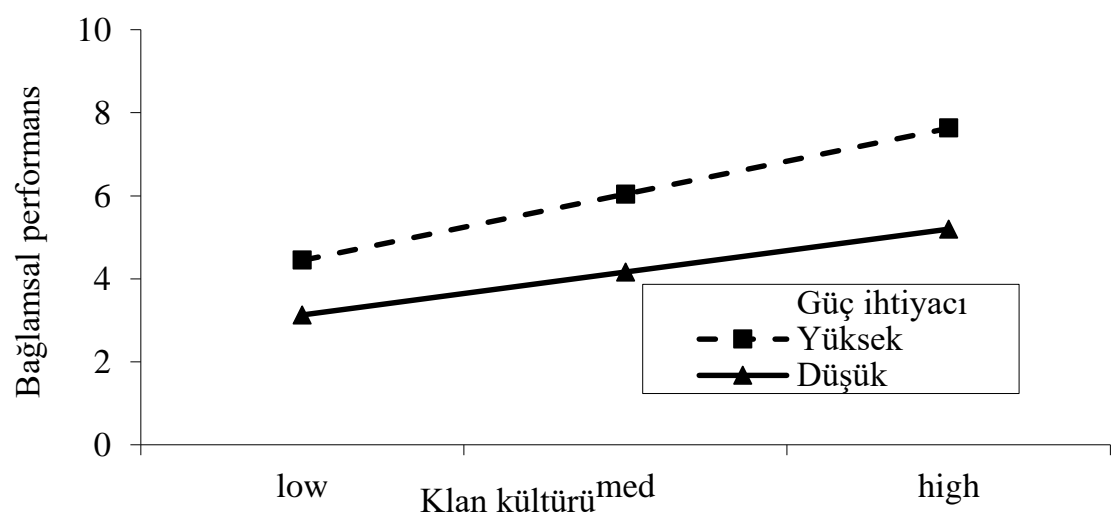

Şekil 4. Hiyerarşi Kültürü ile Bağlamsal Performans Arasındaki İlişkide Başarı İhtiyacının Rolü

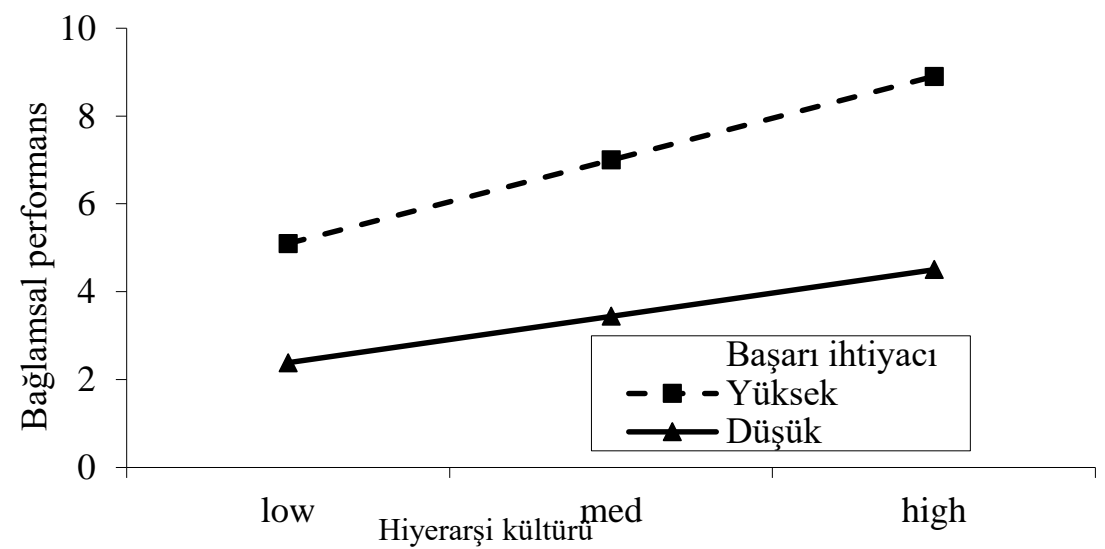

Şekil 5. Hiyerarşi Kültürü ile Bağlamsal Performans Arasındaki İlişkide Güç İhtiyacının Rolü

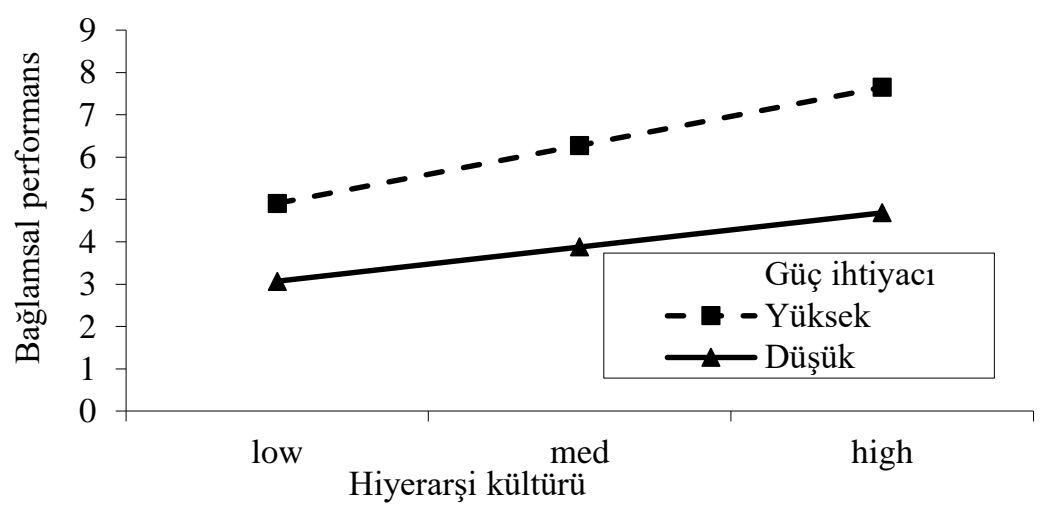


Düzenleyici etki grafikleri, klan kültürü-bağlamsal performans ilişkisinde güç ihtiyacının (Şekil 3), hiyerarşi kültürü-bağlamsal performans ilişkisinde başarı ihtiyacının (Şekil 4) ve hiyerarşi kültürü-bağlamsal performans ilişkisinde güç ihtiyacının (Şekil 5) düzenleyici ve söz konusu ilişkilerin gücünü artırıcı yönde rol oynadığını göstermektedir. Buna göre, klan kültürü ile güç ihtiyacının, hiyerarşi kültürü ile başarı ihtiyacının ve hiyerarşi kültürü ile güç ihtiyacının en yüksek olduğu noktalar, aynı zamanda bağlamsal performansin en yüksek olduğu noktalardır. Diğer bir deyişle, klan kültürüne sahip örgütlerde istihdam edilen havacılık sektörü çalışanlarının, güç ihtiyaçlarının yüksek olması durumunda, bağlamsal performansı anlamlı biçimde daha yüksek gerçekleşmektedir. Aynı şekilde, hiyerarşi kültürüne sahip örgütlerde istihdam edilen havacılık sektörü çalışanlarının, başarı ve güç ihtiyaçlarının yüksek olması durumunda, bağlamsal performansı anlamlı biçimde daha yüksek gerçekleşmektedir.

\section{Tartışma ve Sonuç}

Havacılık ve özelinde uçuş deneyimi, pilotun uçağın motorunu çalıştırması, uçması ve tekrar motoru susturması şeklinde bir silsile izleyen, basit bir süreç gibi gözükmesine rağmen; formel ve enformel ağlarla örülmüş, özgün değerleri ve yazılı olmayan kuralları bulunan, sadece havacılık ile meşgul olanların anlayabileceği bir terminolojisi, semboller kümesi, maceraları ve efsaneleri olan, başlı başına farklı bir sektörü temsil etmektedir. Bu çalışma, havacılık sektöründe çalışanların örgüt kültürü tiplerine dair algılarını, bu algıların iş performansının bir bileşeni olan bağlamsal performansa etkisini ve temel motivasyon kaynaklarının bu süreçteki rolünü incelemek üzere tasarlanmıştır.

Havacılığın vikipedisi olarak anılan skybrary'de yer alan ve Uluslararası Sivil Havacılık Örgütü'nün Emniyet Yönetimi El Kitabından esinlenerek yazılan bir makalede, örgüt kültürünün havacılık sektörü açısından en önemli unsurunun ve sonucunun, hayati önem arz eden emniyet kültürünün ve emniyet ikliminin yerleştirilmesi noktasındaki rolü olduğuna vurgu yapılmaktadır (Skybrary; SHGM, 2013). Nitekim örgüt kültürü, çalışanların günlük faaliyetleri gerçekleştirme biçimlerine ilişkin normları ve değerler sistemini belirlemekte ve operasyonlara ilişkin birtakım sınırlar çizmektedir. Operasyon personelinin emniyetle ilgili raporlamaları, uygulamaları ve prosedürleri gerçekleştirme biçimi, örgüt kültürünün bir uzantısı olmaktadır. Genelde ulusal kültür ile mesleki kültür, özelde ise örgüt kültürünün kesiştiği noktada, a) insanlar arası ilişkiler, b) bilginin paylaşımı, c) zorlu iş koşullarında çalışanların vereceği tepkiler, d) yeni teknolojinin benimsenme düzeyi, e) otoriteye verilecek tepkiler, f) belgelendirme işlemleri, g) eğitim ve yetiştirme/geliştirme programlarının hazırlanması ve uygulanması, h) farklı çalışma gruplarıyla iş birlikleri ve görev dağılımları, i) yönetim ve sendikalarla ilişkiler gibi çok sayıda mesele ve bunların örgüt performansı üzerindeki etkileri ortaya çıkmaktadır (Kind, 2004). Örgüt kültürünün önemi, işte bu kapsamlı çerçevede havacılık örgütlerinin gündemine taşınmaktadır. Yine, havacılık örgütlerinin olmazsa olmazı emniyet yönetim sistemlerinin başarıs1, örgüt kültürünün uyumluğuyla ve uygunluğuyla doğru orantılıdır (Broyhill ve Freiwald, 2012). 
Diğer taraftan, Baltık Havacılık Akademisi'nin (BAA, 2013) örgüt kültürünün sektördeki önemine ithafen yayınladığı bildiride, emniyetin sağlanmasında ve pozitif emniyet kültürünün yerleştirilmesinde "emniyet yönetim sistemlerinin" etkililiğinden ziyade çalışanların sorumluluğunun ve katkısının önemine vurgu yapılmaktadır. Meslekteki sosyal normların ve teşvik sistemleri ile düzenlenmesi mümkün olan örgüt kültürünün, bilginin paylaşılması ve kritik faaliyetlerin/davranışların düzenlenmesi, stresin yönetilmesi, insan kaynaklı hataların indirgenmesi konularındaki rolünün altı çizilmektedir. Nitekim, bireyi doğduğu günden itibaren kuşatan, davranışlarına ve düşünce dünyasına yön veren toplumsal kültürün değişime dirençli yapısına karşın, örgüt kültürünün istenilen yönde şekillendirilmesi görece daha kolaydır. Havacılık örgütlerinde hâkim olan örgüt kültürü tiplerinin tespit edilmesi ve pozitif çıktılarla ilişkilendirilmesi yönünde atılacak adımlar bu açıdan önem kazanmaktadır. Havacılık emniyet sistemlerinin geçtiğimiz yüzyılın özellikle ikinci yarısından sonra hızla gelişmesi, mekanik iyileştirmeler ve insan/iş gücü odaklı iyileştirmeler olmak üzere iki ana cephede seyretmiştir. Donanımsal açıdan sağlanan iyileştirmeler mühendislik ve teknolojideki gelişmelerden beslenirken, insanla ilgili iyileştirmeler eğitim, yetiştirme ve gelişme ve süreç etkileşimlerine dayanmaktadır. İnsanla ilgili cephede kat edilen mesafe, emniyet kültüründen ve özelde örgüt kültüründen bağımsız değerlendirilememektir.

Genel olarak ele alındığında, araştırmaya katılan havacılık sektörü çalışanları örgütlerinin en fazla hiyerarşi ve klan kültürü tipine yakın olduğunu, en az ise adhokrasi kültürüne benzediğini düşünmektedir. Emniyet, kural ve prosedürlerin başlıca öncelikler olarak gözetildiği, belirlenmiş iş akışlarının izlendiği ve havacılık otoritelerince düzenli olarak denetlenen havacılık örgütlerinde, durağan ve kontrol odaklı, içe dönük örgüt tipleri olarak gruplanan klan ve hiyerarşi kültürlerinin daha baskın olması, normatif gerekliliklerle anlamlandırılabilir bir sonuç olarak karşımıza çıkmaktadır. Nitekim, sektörün uluslararası örgütlerce düzenlenen yasa ve yönetmeliklere yoğun biçimde maruz kalması, kaçınılmaz bir hiyerarşi kültürü üretmektedir. Havacılık sektöründe farklı kademelerde ve birimlerde çalışan işgörenler üzerine yapılan bir araştırmada (Lumpe, 2008) mavi yakalı çalışanların patriarkal bir liderliğe ihtiyaç duydukları ve açık yönlendirme ile destekleyici/koruyucu tutum sergileyen liderler istedikleri tespit edilmiş; bu bağlamda en uygun yönetim tarzının Fayolcu idari yönetimi temsil eden türden hiyerarşik bir düzenleme olacağı iddia edilmiştir.

Havacılık örgütlerinde iş süreçleri ve biçimsel ilişkilerin kuralları sıkı sıkıya belirlenmiş olmasına rağmen, başta havacılığın olmazsa olmazı emniyet yönetim sistemi süreçlerinde olmak üzere, örgütler çalışanlarından rol ötesi davranışlar sergilemelerini beklemektedir. Örneğin, Sivil Havacılık Genel Müdürlügü (SHGM) tarafından yayımlanan "Havaalanlarında Emniyet Yönetim Sisteminin Uygulanmasına İlişkin Talimat” içerisinde yer alan EK-1 örnek emniyet politikası beyanında, "Çalışanların gönüllü katılımını desteklemek, ölçmek ve artırmaya yönelik stratejiler geliştirmek" şeklinde bir kurumsal taahhüde yer verilmektedir. $\mathrm{Bu}$ araştırmanın bulgularına bakıldığında, örgüt kültürü tiplerinin 
tamamı ile bağlamsal performans arasında orta düzeyde ve pozitif yönde korelasyon bulunmaktadır. Bağlamsal performans ile en yüksek düzeyde ilişkiler, klan ve pazar kültürü boyutlarında görülmektedir. Klan kültürünün ailevi bir atmosfer ve ilişkilerde samimiyetin önemsendiği bir ortam sunması, bağlamsal performans sergileme eğilimini artırıcı rol oynayabilir. Özünde bu durum, Türk toplumsal kültünün toplulukçu özelliği ile tutarl1lık arz etmektedir. Paine ve Organ (2000), örgüt kültürünün, büyük ölçüde örgütün içinde bulunduğu ulusal kültürel bağlamdan etkilenebileceği ve kültürel etkileri taşıyacağını belirtmektedir. Diğer taraftan, esnek örgüt kültürlerinin daha yüksek düzeylerde iş tatmini ile ilişkilendirildiği (Waris, 2005) ve pazar kültürünün çalışanların tatminini artırıcı bir rol oynadığı da araştırmalarda ortaya konmuştur. Artan çalışan tatmininin bağlamsal performans olarak fiile dönüşmesi muhtemeldir (Swaminathan ve Jawahar, 2013).

Güçlü ve pozitif duyguları tetikleyen bir örgüt kültürünün, çalışanların bağlılık, iş birliği yapma ve özdeşleşme gibi tutumlarını etkileyeceği belirtilmektedir. İş performansı açısından ise güçlü veya kurumsal bir örgüt kültürünün varlığı görev performansı noktasında hayati olmasa da örgüt kültürünün, çalışanların gönüllü ve rol ötesi davranışlarda bulunma motivasyonlarını desteklemesi bağlamsal performans açısından kritik önem taşımaktadır (Zhang, 2016). Örgütün değerlerini içselleştiren, örgütü evi addeden, kişisel gelişimini ve geleceğini örgütün yarını ile bağdaştıran çalışanların fazladan çaba sarf etme, görevlerin tamamlanması için diğerlerine yardımcı olma ve örgütün amaçlarını önceliklendirme eğilimi artmaktadır.

Her örgütün temel değerleri, normları, kuralları, öncelikleri ile performans hedefleri ve çalışanlarından beklentileri farklı olup, bu unsurlar örgütün kültürel belleğine kodlanmaktadır. Çalışanların ortaya koyması arzulanan performans, kültürün bir uzantısı haline gelmektedir. Dahası, performansın ortaya çıkmasında bağlamın önemini vurgulayan kişi-durum etkileşim modeline (Tett ve Burnett, 2003) göre durumsal ipuçları ve mesajlar, spesifik olarak ise örgüt iklimi ve kültürü performansın nasıl gerçekleşeceğini belirleyici olmaktadır. Çalışanların kişilik özellikleri ile yakından ilişkili olan temel motivasyon kaynaklarının örgüt kültürünün teşvik ettiği değerler ile uyumlu olduğu noktada ise rol ötesi performansta artış olacağı değerlendirilebilir. Nitekim, beş büyük kişilik özelliklerinden sorumluluk türü kişiliği ağır basanların aynı zamanda başarı ihtiyacının yüksek olacağı ve bu kişilerin sonuç odaklı kültürlerde çalışması durumunda bağlamsal performanslarının daha yüksek gerçekleşeceği belirtilmektedir (Wang, Begley, Hui ve Lee, 2012).

Klan kültürü ile güç ihtiyacı etkileşiminin bağlamsal performans üzerindeki anlamlı etkileri, klan kültürünün en çok vurgulanan ikinci kültür olması ve bağlamsal performans ile en yüksek oranda ilişkilenen kültür tipi olması ile birlikte okunduğunda, ülkenin toplumsal kültürünün taşma etkisiyle örgütlere uzandığı bir kez daha görülmekte, sosyal sermayenin, ilişkilerin, bağların ve bağlantıların önemi ortaya çıkmaktadır. Kişi-örgüt uyumunun ve kişinin değerleri ile örgütsel bağlama özgü değerler sisteminin uyumluluğu (Chatman, 1991: 459) 
çalışanların örgüt içerisindeki tutum ve davranışlarını doğrudan şekillendirmektedir. Bu noktada, kişilerin belirli bir işi yapmaya uygun yetkinliklere sahip olmasından ziyade, belirli bir örgütün özellikleri, örgütün "kişiliği" ve değerleri ile uyumlu olması daha önemli bir işe alma kriteri haline gelebilmektedir (Bowen, Ledford ve Nathan, 1991). Klan tipi örgütlerde liderlerin anne-baba figürü olarak görülmesi, çatışmaların minimum seviyede tutulması, çalışanların moral ve bağlılığına önem verilmesi, çalışanların güç ihtiyacı ile birleştiğinde bağlamsal performans üzerinde anlamlı sonuçlar görülmüştür. Çalışan tatmininin maddi kazanımlardan daha önemli olduğu, arkadaşlık ilişkilerinin öne çıktığ 1 , örgütsel uyuma önem verilen, biçimselleşmenin düşük ve örgütsel geleneklerin ise bol olduğu, insan odaklı yapılar olarak tanımlayabileceğimiz klan kültüründe (Erdem, 2007b) bağlamsal performansın yüksek olması Türk tipi örgütlerin çalışanlarının güçle ile algılarını ve güce verdikleri tepkiyi yansıtmaktadır. Gücün ilişkilerden doğduğu yönündeki yerleşik inanış ve diğerlerini etkilemek için en başta sosyal etki/nüfuz/politika gibi kaynakları ele geçirmek gerektiği anlayışı, klan kültürünün temel varsayımları ile uyumlu ve bağlamsal performans ile yakından ilişkili unsurlar olarak tespit edilmiştir.

Hiyerarşi kültürü ile başarı ihtiyacı etkileşiminin bağlamsal performans üzerindeki anlamlı ve ilişkinin gücünü artırıcı yöndeki etkileri, belirsizlikten kaçınma yönelimli, bürokratik, durağan ve kontrolcü bir kültürün de pekala rol ötesi davranışları teşvik edebileceğini göstermesi açısından kritiktir. Bu noktada, zaman yöneliminin kısa, belirsizlikten kaçınmanın yüksek olduğu Türkiye gibi dar bağlamlı kültürlerin T tipi örgütlerinde (Mittal ve Elias, 2016; Sargut, 2015; Dirik, Eryılmaz ve Altın-Gülova, 2017), pozisyondan ileri gelen otoritenin kullanımı, etkili bir yönetim tarzı olabilmekte ve olumsuz duygular yaratmaksızın bağlamsal performans üretebilmektedir. Başarı ihtiyacının bağlamsal performans üzerindeki pozitif etkilerinin statükocu olmak, değişime direnç ve inovasyona ket vurmak gibi eleştirilere maruz kalan hiyerarşi kültürünce dahi baskılanmaması, aksine bu etkileşimin ilişkinin gücünü artırıcı rol üstlenmesi, toplumsal kültürün yarattığ postmodern türden bir "karşıtllkların birlikteliğì" olarak yorumlanabilir. Görünürde, zıt iki pozisyonu temsil eden hiyerarşi eğilimi ile esnekliğin ve çalışanların güçlendirilmesinin bir uzantısı olduğu varsayılan bağlamsal performansın bir arada ele alındığı bu model, havac1lık sektörünün özgün doğas1 ile anlamlandırılabilir. Emniyetin, yalnızca pahalı ekipmanların korunması veya vitrincilik kaygısıyla değil, insan yaşamının ve var oluşunun her anlamda önceliklendirilmesi felsefesiyle vurgulandığı havacılık sektöründe, yine insan yaşamının kutsallığı adına taviz verilmeyen bir hiyerarşik düzenin varlığı, çalışanlarca olumlu karşılanmış ve mübadele edilmiş görünmektedir.

Son olarak, hiyerarşi kültürü ile güç ihtiyacı etkileşiminin bağlamsal performans üzerindeki anlamlı etkileri, gücün meşru, pozisyon kaynaklı ve sert (yumuşak güce karşı) temellerinin (French ve Raven, 1959; Raven, 1993) havacılık sektörü çalışanlarınca kanıksanmış bir durum olduğunu; halihazırda yönetici pozisyonunda olmayan katılımcıların yöneticileri ile sürdürdükleri hiyerarşiye duyarlı ast-üst ilişkilerini benimsediklerini göstermektedir. Bir bütün olarak 
araştırmanın veri toplamın ve anket yöntemi bağlamında birtakım kısıtları mevcuttur. İlk olarak havacilık sektörünün yoğunluğu nedeniyle istirahat vakitlerinde sektör çalışanlarından anketleri doldurması istenmiş, çalışanlar üzerinde oluşan zaman baskısı araştırmacılar tarafından gözlemlenmiştir. Bu kısıttan hareketle zaman baskısı olmadan ve anket yöntemi ile birlikte derinlemesine mülakat ile baskın örgüt kültürü algısının anlaşılması sonraki çalışmalar açısından önemli olduğu değerlendirilmektedir. Örgüt kültürü haricinde bağlamsal performansın değerlendirilmesinde de üstlerin görüşlerini astların beyanlarıyla birlikte değerlendirmenin, katılımcıların sosyal beğenirlik endişelerini kontrol altına alma açısından faydalı olacağı değerlendirilmektedir.

\section{KAYNAKÇA}

Acar, A. Z. (2013). Farklı örgüt kültürü tipleri ve liderlik tarzları ile örgütsel bağl1lık arasındaki ilişki: Lojistik işletmelerinde bir araştırma. İşletme Araştırmaları Dergisi, 5(2), 5-31.

Aiken, L. S., \& West, S. G. (1991). Multiple regression: testing and interpreting interactions. Newbury Park: Sage.

Alvesson, M. (2002). Understanding organisational culture. London: Sage Publications.

Antalyalı, Ö. L., \& Bolat, Ö. (2017). Öğrenilmiş ihtiyaçlar bağlamında temel motivasyon kaynakları (TMK) ölçeğinin geliştirilmesi, güvenilirlik ve geçerlik analizi. AIBB̈̈ Sosyal Bilimler Enstitüsü Dergisi, 1(17), 83-114.

Aydıntan, B., \& Aktan, E. (2016). Cameron-Freeman örgüt kültürü türleri ekseninde örgüt kültürü ve bilgi güvenliği algısı ilişkisi: devlet üniversitelerinde bir uygulama. Journal of Business ResearchTurk, 8, 324-324.

BAA (2013). https://www.baatraining.com/the-importance-of-organizational-culture-in-aviation/. Erişim Tarihi: 22. 01. 2019).

Bağcı Z. (2014). Çalışanların iş doyumunun görev ve bağlamsal performansları üzerindeki etkisi. Yönetim ve Ekonomi Araştırmaları Dergisi, 24, 58-72.

Barnouw, V. (1979). Culture and Personality (3rd ed.). Homewood, IL: Dorsey Press.

Berrio, A.A. (2003) An organizational culture assessment using the competing values framework: A profilie of Ohio state university extension. Journal of Extension, 41(2),1-22.

Blakely, G. L., Andrews, M. C., \& Fuller, J. (2003). Are chameleons good citizens? a longitudional study of the relationship between self monitoring and organizational citizenship behavior. Journal of Business and Psychology, 18(2), 131-144.

Borman, W.C., \& Motowidlo, S.J. (1997). Task performance and contextual performance: the meaning for personnel selection research. Psychology Faculty Publications. 1100.

Bowen, D. E., Ledford, Jr. G. E., \& Nathan, B.R. (1991). Hiring for the organization, not the job. Academy of Management Perspectives, 5(4), 35-51.

Broyhill, C., \& Freiwald, D. (2012). CRM and SMS: Directing the evolution of aviation organizational culture. Paper presented at the CASS: 57th annual Corporate Aviation Safety Seminar. San Antonio, TX.

Cameron, K. S., \& Freeman, S. J., (1991). Cultural congruence, strength and type: relationships to effectiveness. Research in Organizational Change and Development, 5, 23-58.

Cameron, K. S., \& Quinn, R. E. (2006). Diagnosing and changing organizational culture, Jossey Bass Publications, San Francisco.

Chatman, J.A. (1991). Matching people and organizations: selection and socialization in public accounting firms. Administrative Science Quarterly, 36(3), 459-484.

Çavuşoğlu, S., \& Köse, S. (2016). Örgüt kültürünün örgütsel sessizlik davranışına etkisi. Dokuz Eylül Üniversitesi Sosyal Bilimler Enstitüsü Dergisi, 18(1), 115-146.

Çetin, A., \& Topaloğlu, C. (2018). Otel işletmelerinde cameron-quinn örgüt kültürü tiplerinin yenilikçiliğe etkisi. Journal of Tourism and Gastronomy Studies, 6(2), 476-492.

Çetin, F., Şeşen, H., \& Basım, H. N. (2012). Örgüt kültürünün rol ötesi olumlu davranışlara olan etkisi: örgütsel bağlılığın aracı değişken rolü. Doğuş Üniversitesi Dergisi, 13(2), 197-211. 
Danışman, A., \& Özgen, H. (2003). Örgüt kültürü çalışmalarında yöntem tartışması: Nitelikselniceliksel yöntem ikileminde niceliksel ölçümler ve bir ölçek önerisi. Yönetim Araştırmaları Dergisi, 3(2), 91-124.

Dirik, D., Eryılmaz, İ., \& Altın Gülova, A. (2017). Liderin yumuşak ve sert güç kaynakları ile çalışan performansı arasındaki ilişkilere yönelik bir araştırma: Tarafların cinsiyetinin düzenleyici rolü. Uluslararası İktisadi ve İdari İncelemeler Dergisi, 1-20.

DuBrin, A.J. (2005). Fundamentals of Organizational Behavior. Louseville, Canada: Thomsan SouthWestern.

Erdem, R. (2007a). Örgüt kültürü tipleri ile örgütsel bağlılık arasındaki ilişki: elazığ il merkezindeki hastaneler üzerinde bir çalışma. Osmangazi Üniversitesi, İktisadi ve İdari Bilimler Fakültesi Dergisi, 2(2), 63-79.

Erdem, R. (2007b). Toplumsal kültürün örgüt kültürüne yansımaları. İçinde: R. Erdem ve Ş. Çukur (Ed.). Kültürel Bağlamda Yönetsel-Örgütsel Davranış (ss. 89-133). Ankara: Türk Psikologlar Derneği Yayınları.

Ersarı, G., İşcan, Ö.F., \& Naktiyok, A. (2016). Kadın ve erkek bakış açısıyla kadın çalışanların kariyer engelleri ve örgüt kültürü ilişkisi: Akademisyenler üzerinde bir uygulama. I Ĭgdır Üniversitesi İ̈BF Dergisi, 1(1), 171-200.

French, J. R. P., \& Raven, B. (1959). The basis of power, In D. Cartwright (Ed.), Studies In Social Power (ss. 529-569). Ann Arbor, MI: University Of Michigan Press.

George, J. M., Jones, G. R., \& Sharbrough, W. C. (2012). Understanding and managing organizational behavior (6 B.). New Jersey: Prentice Hall.

Goodman, S., \& Svyantek, D. (1999). Person-organization fit and contextual performance: Do shared values matter. Journal of Vocational Behavior, 55, 254-275.

Hall, E. T. (1959). The silent language. New York: Doubleday.

Hofstede, G. (1980). Culture's consequences. Beverly Hills, CA: Sage.

Jawahar, I.M., \& Carr, D. (2007). Conscientiousness and contextual performance: the compensatory effects of perceived organizational support and leader-member exchange. Journal of Managerial Psychology, 22, 330-349.

Joiner, T. A. (2001). The influence of national culture and organizational culture alignment on job stress and performance: Evidence from greece. Journal of Managerial Psychology, 16(3), 229-242.

Jun, S., \& Joo, B.K. (2011). Knowledge sharing: the influences of learning organization culture, organizational commitment, and organizational citizenship behaviors. Journal of Leadership \& Organizational Studies, 18(3), 353-364.

Kandemir, H., Tekeli, İ., \& Özdaşlı, K. (2016). Örgüt kültürünün düşük ve yüksek bağlamlı iletişim tarzları üzerine etkisi: Kafe çalışanları üzerine çalışma. Selçuk Üniversitesi Sosyal ve Teknik Araştırmalar Dergisi, 11, 202-222.

Karakurum, M. (2005). The effects of person-organization fit employee job satisfaction, performance and organizational commitment in a turkish public organization. Yayınlanmamış Doktora Tezi, Orta Doğu Teknik Üniversitesi, Ankara.

Karcıoğlu, F., \& Timuroğlu, M. K. (2004). Örgüt kültürü ve liderlik. Atatürk Üniversitesi İ.I.B.F. Dergisi, 2, 319-338.

Kind, P. J. (2004). The influence of organization culture on aviation safety - A case study of a United states navy fa-18 landing mishap. Master's Thesis, University of Tennessee.

Koçel, T. (2011). İşletme yöneticiliği. 13. Baskı, İstanbul: Beta Basım Yayın.

Köse, S., Tetik, S., \& Ercan, C. (2001). Örgüt kültürünü oluşturan faktörler. Yönetim ve Ekonomi Dergisi, 7(1), 219-242.

Kraimer, M. (1997). Organizational goals and values: A socialization model. Human Resource Management Review, 7, 425-447.

Kroeber, A. L., \& Parsons. T. (1958). The concepts of culture and of social system. American Sociological Review, 23, 582-583.

Kuşcu, P. (2011). İşyeri zorbalığı ve örgüt kültürü ilişkisi üzerine sosyolojik bir araştırma. Uluslararası Sosyal Araştırmalar Dergisi, 19(4), 371-394. 
Lumpe, M. L. (2008). Leadership and organization in the Aviation Industry. Ashgate Publishing: England.

Mcclelland, D. C. (1961). The achieving aociety. New York: Van Nostrand Reinhold.

Mcclelland, D. C. (1985). Human motivation. Glenview, Il: Scott Foresman.

Meydan, C.H., Dirik, D., \& Eryılmaz, İ. (2018). Liderin güç kaynakları ve iş performansı arasındaki ilişkide pelz etkisinin düzenleyici rolü. Yönetim ve Ekonomi: Celal Bayar Üniversitesi İktisadi ve İdari Bilimler Fakültesi Dergisi, 25(1), 75-92.

Mittal, R., \& Elias, S. M. (2016). Social power and leadership in cross-cultural context. Journal of Management Development, 35(1), 58-74.

Motowidlo, S. J., Borman, W. C., \& Schmit, M. J. (1997). A theory of individual differences in task and contextual performance. Human Performance, 10(2), 71-83.

Ojo, O. (2009). Impact assessment of corporate culture on employee job. Journal of Business Intelligence, 2(2), 389-399.

Oral-Ataç, L. (2018). Adhokratik Örgüt Yapıları. İçinde: E. Aydoğan (Ed.), Örgütsel Davranış Odaklı Yönetsel Yaklaşımlar. Gazi Kitabevi: Ankara.

Ouchi, G. (1987). Teori Z: Japonların Yönetim Tarzı Nasıl İşliyor. Çev.Yakut Güneri, İstanbul: İlgi Yayınc1lik.

Paine, J.B., \& Organ, D.W. (2000). The cultural matrix of organizational citizenship behavior some preliminary conceptual and empirical observations. Human Resource Management Review, 10(1), 45-59.

Paşamehmetoğlu, A., \& Yeloğlu, H.O. (2013). Motivasyon. İçinde: Sığrı, Ü. \& Gürbüz, Ü. (Ed) Örgütsel Davranış. İstanbul: Beta Yayınları.

Raven, B.H. (1993). The bases of power: origins and recent developments. Journal of Social Issues. 49, 227-251.

Reilly, R.R., \& Aronson, Z. H. (2012). Managing contextual performance (December 24, 2012). Available at SSRN:https://ssrn.com/abstract=2193645.

Sargut, A.S. (2015). Kültürler arası farklılaşma ve yönetim, Ankara: İmge Kitabevi.

SHGM (2013). Havaalanlarında emniyet yönetim sisteminin uygulanmasına ilişkin talimat (SHTSMS/HAD). http://web.shgm.gov.tr/doc4/sht-sms-had.pdf

Skybrary. https://www.skybrary.aero/index.php/Organisation al_Culture (Erişim Tarihi: 23.01.2019).

Swaminathan, S., \& Jawahar, P. D. (2013). Job satisfaction as a predictor of organizational citizenship behavior: an empirical study. Global Journal of Business Research, 7(1), 71-80.

Şeşen, H. (2013). Örgüt Kültürü. İçinde: Ü. Sığrı ve S. Gürbüz (Ed.), Örgütsel Davranış (ss.545-582). İstanbul: Beta.

Tayeb, M.H. (1988). Organisations and national culture. London: Sage Publications.

Tett, R. P., \& Burnett, D. D. (2003). A personality trait-based interactionist model of job performance. Journal of Applied Psychology, 88, 500-517.

Topaloğlu, M., \& Kara, D. (2004). Örgütsel kültürün yöneticilerin yönetsel davranışları üzerindeki etkileri-a grubu seyahat acentelerinde bir uygulama. Gazi Üniversitesi Ticaret ve Turizm Eğitim Fakültesi Dergisi, 2, 121-141.

Van Scotter, J., Motowidlo, S., \& Thomas, C.C. (2000). Effects of task performance and contextual performance on systemic rewards. The Journal of Applied Psychology, 85, 526-535.

Wang, H., Begley, T., Hui, C., \& Lee, C. (2012). Are the effects of conscientiousness on contextual and innovative performance context specific? organizational culture as a moderator. The International Journal of Human Resource Management, 23(1), 174-189.

Waris, R.G. (2005). An examination of organizational culture, employee attitudes, and organizational citizenship behavior: a path analysis approach. PhD Thesis, University of MissouriColumbia, Kansas City, United States of America.

Yücel, İ., \& Koçak, D. (2014). Örgüt kültürü ile örgütsel bağlılık arasındaki ilişkiye yönelik bir araştırma. Erzincan Üniversitesi Sosyal Bilimler Enstitüsü Dergisi, 7(2), 45-64.

Zhang, W.J. (2016). Relationship between organizational culture 1dentity and job performance of enterprise employees. 3rd International Conference on Advanced Education and Management (ICAEM 2016). 


\section{SUMMARY}

Although the experience of aviation and in particular flight seems to be a simple process, followed by a sequence in which the pilot starts the engine, flies and shuts down the engine; it represents a distinct sector in its own, with formal and informal networks, with unique values and unwritten rules, a terminology, a set of symbols, adventures and legends that only those engaged in aviation can understand. This study was designed to examine the perceptions of 265 participants working in the aviation sector on organizational culture types, the effect of these perceptions on contextual performance, which is a component of business performance, and the role of basic motivation sources in this process. This purpose has been reached in Turkey's aviation sector employees in four different provinces, it was administered questionnaire that included demographic variables and scale of research.

In general, the aviation sector workers participating in the survey indicated that their organizations were most close to the hierarchy and clan culture type. This is explained by the more dominant culture of clans and hierarchies grouped as static and control-oriented, inward-looking organization types in aviation organizations where safety, rules and procedures are considered as top priorities, monitored workflows are monitored and regularly monitored by aviation authorities. It is stated that an organizational culture that triggers strong and positive emotions will affect the attitudes of employees such as loyalty, cooperation and identification. In terms of business performance, the existence of a strong or corporate organizational culture is not vital to the performance of the task, but it is critical for the contextual performance that the organizational culture supports the motivation of the employees to perform voluntary and cross-role behaviors. Correlation analysis results support this situation.

The basic values, norms, rules, priorities, performance goals and expectations of employees of each organization are different and these elements are coded into the cultural memory of the organization. The performance desired by the employees becomes an extension of the culture. Moreover, situational clues and messages, and organizational climate and culture, determine how performance will be realized according to the person-state interaction model, which emphasizes the importance of context in the emergence of performance. It can be considered that there will be an increase in the performance of the role when the main sources of motivation, which are closely related to the personality traits of the employees, are compatible with the values encouraged by the organizational culture. The effect of the interaction of hierarchy culture and the need for success on contextual performance and increasing the strength of the relationship supports this result. Moreover, the meaningful effects of clan culture and power need interaction on contextual performance are read with the fact that clan culture is the second most emphasized culture and the type of culture that has the highest correlation with contextual performance, it is once again seen that the social culture of the country extends to organizations due to overflow and social capital The importance of relations, ties and connections emerges. As a result, it is critical to show that a 
bureaucratic, static and control culture oriented towards avoiding uncertainty may well promote the role-playing behavior. At this point, short of time orientation, is high uncertainty avoidance by Turkey as narrow-context cultures of T-type use the authority of elders from positions in the organization, to become effective management style and negative feelings without causing said based on the findings of research that generate contextual performance. 